\title{
"UNA EXIGENCIA DE LA LETRA MISMA": AMANDA BERENGUER ANTE LA PUESTA EN VOZ DE SU POESÍA
}

\author{
POR \\ MARÍA Lucía PuPPo ${ }^{1}$ \\ Universidad Católica Argentina-CONICET
}

\section{Poesía, SONIDO, SENTIDO}

En sus ensayos de los años cuarenta dedicados a examinar el vínculo entre la imaginación y la realidad, Wallace Stevens se propuso demostrar la interdependencia que existe entre ambas instancias en todos los órdenes, incluidos los del arte y la poesía. Según el razonamiento de Stevens, si la imaginación es inseparable de la realidad, entonces resulta inoperante y falsa la distinción entre un poema centrado en las formas y un poema socialmente comprometido. La única obligación de la poesía es, ni más ni menos, "ayudar a la gente a vivir sus vidas" (Stevens 121). A diferencia de las otras artes, la poesía logra este objetivo mediante la capacidad comunicativa de las palabras $\mathrm{y}$, especialmente, de sus sonidos. Y proseguía el poeta estadounidense:

No sé de nada que parezca haber sufrido más y haya sufrido menos a través del paso del tiempo que la música de la poesía. La profunda necesidad de palabras que expresen nuestros pensamientos y sentimientos, los cuales, estamos seguros, son toda la verdad que jamás experimentaremos, junto al hecho de que no tenemos ilusiones, nos hace escuchar las palabras cuando las oímos, amarlas, sentirlas; nos hace buscar su sonido de acuerdo a un fin, a una perfección, a una vibración inalterable, que sólo la capacidad del poeta más agudo puede otorgarles. (122-23)

La cita comienza con otra de las paradojas de Stevens: aunque mucho se hable y se escriba en su contra, a través de los siglos y las culturas nunca ha desaparecido "la música de la poesía". Y esto no se debe a una obsesión lírica o a un delirio preciosista de los poetas de todas las épocas, sino a la "profunda necesidad" expresiva que nos caracteriza a los seres humanos. Desde esta perspectiva el discurso poético de la modernidad no se entiende como un fenómeno preeminentemente escriturario, textual, cuya metáfora

1 Centro de Estudios de Literatura Comparada "María Teresa Maiorana”, Facultad de Filosofía y Letras, Universidad Católica Argentina, CONICET. 
más representativa es la soledad del poeta frente a la página en blanco, sino que, por el contrario, la poesía se manifiesta como un acontecimiento interpersonal que tiene lugar en un tiempo y un espacio concretos, una experiencia única que despierta los sentidos, las sensaciones y los afectos de quienes llegan a su encuentro.

La síntesis del argumento de Stevens se formula en estos términos: "la poesía es palabra", y "la palabra, por sobre todo es, en poesía, sonido" (123). En esta ecuación, desde luego, el sentido es el cuarto factor implicado. Hasta aquí la vía del poeta. Pero ¿cómo se ha abordado este tema desde el discurso teórico sobre la poesía?

Recuperando las agudas reflexiones de creadores como Gerard Manley Hopkins y Paul Valéry, así como las propuestas de W. Wimsatt y M. Beardsley, de los formalistas y de Jan Mukařovský y otros miembros del Círculo de Praga, Roman Jakobson arribó a la conocida tesis enunciada en "Lingüística y Poética": "En poesía, toda semejanza perceptible de sonido se evalúa con relación a la semejanza y/o desemejanza de significado" (Jakobson 385). Jakobson dedicó gran parte de este famosísimo ensayo a analizar diversos casos de "simbolismo acústico" en poemas de distintas lenguas-rimas, acentuaciones, paronomasias, paralelismos, acumulaciones de fonemas o contrastes entre estructuras fónicas- que funcionan como una auténtica "corriente subterránea de significación", según la metáfora de Poe (Jakobson 386). De modo que Jakobson y la crítica estructuralista coinciden en este punto con Stevens; el sonido en poesía no es solo un vehículo sensible del significado, es decir un significante, sino que él mismo posee un valor semántico.

Mientras que la lingüística saussuriana nos enseña tajantemente la arbitrariedad del vínculo entre sonido y significado, la poesía parece querer hacer suyo el viejo sueño del Cratilo platónico: la utopía de un lenguaje cuya materialidad sonora pudiera transparentar su contenido referencial. Frente al abismo que separa los signos verbales de las cosas del mundo, el poema ofrecería el puente -por demás subjetivo y precario- de la mimología fónica (Genette 8 ). En este punto central podrían coincidir acaso Mallarmé, Claudel y Ponge con los tratadistas renacentistas que evaluaban el placer auditivo (voluptas aurium) en el marco de la "teoría de los efectos sonoros" (Vega Ramos 286).

Los numerosos intentos de definición y análisis de la poesía moderna proveen un arsenal de conceptos orientados a describir y explicar la dimensión sonora de los textos. El más importante es el concepto de ritmo, que se remonta a los orígenes de la lírica y que a comienzos del siglo veinte atrajo prioritariamente la atención, como es sabido, de los formalistas rusos. Según estos críticos, así como el ritmo musical determina la distribución de los sonidos en el tiempo, el ritmo verbal es un movimiento anterior al verso (Brik 108), que resulta dominante en la construcción de la lengua poética (Tiniánov 27). Desde una concepción amplia, el ritmo no solo atañe a los elementos fónicos y los esquemas métricos, sino que afecta a toda la organización lingüística y semántica de un poema (Domínguez 58).

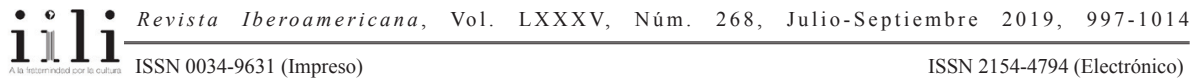


La voz es otra categoría que alude al plano sonoro de la poesía. Raúl Dorra apunta que la voz designa "la presencia del sujeto en su particularidad, en su estar-ahí-ahora" (36). Toda voz arroja fuera de sí, es siempre in-vocación a otro; además crea una atmósfera, como lo sugiere la etimología común de los términos alemanes Stimme y Stimmung (Agamben 90). Oír es ser colmado por una voz: quizás esta experiencia primigenia nos defina desde recién nacidos. La emisión de sonidos es común a los seres humanos y los animales, pero la voz de Dios antecede al mundo, predican las religiones monoteístas. La voz media entre el cuerpo y el lenguaje, sin pertenecer por entero a ninguno de ellos (Dolar 73). En la enunciación poética la voz introduce los sentidos, o sea el saber del cuerpo, como base de la experiencia y el contacto (Masiello 17).

La oralidad de la poesía escrita no se reduce a un registro coloquial que busca reproducir la espontaneidad del habla cotidiana. Tiene que ver, en cambio, con una inflexión de la voz que el lector interioriza como la voz del "sujeto imaginario" del poema (Monteleone 149). ${ }^{2}$ La figura del sujeto o hablante poético se asimila entonces a la persona en el sentido latino del término, 'máscara' que se utiliza para 'sonar a través' (per-sonare).

En las primeras décadas del siglo veinte las vanguardias impulsaron la búsqueda de una discursividad poética multimedial, que fusionara grafismo, vocalidad, movimiento y acción. Asimismo el desarrollo tecnológico favoreció el surgimiento de nuevas formas de composición y de ejecución ante las audiencias presenciales o mediáticas. En este contexto, la puesta en voz de la poesía resulta un fenómeno específico que, bajo diferentes modalidades, sitúa en un primer plano la materialidad fónica del texto. Como explica Luis Bravo, en el trayecto de la letra escrita a la puesta en voz "el poema recupera algo que le es propio a su naturaleza: el ser un objeto de lenguaje compuesto para la voz de quien dice y para el oído de quien escucha, además de para la vista y oído interno del lector" ("La puesta en voz" 15).

En este trabajo nos proponemos analizar y comparar dos instancias de puesta en voz de la poesía de Amanda Berenguer. La autora uruguaya realizó grabaciones de sus textos en dos etapas distintas de su trayectoria poética y vital, que ponen de manifiesto motivaciones y estrategias muy diferentes entre sí. Nos interesa examinar estos textos en audio como ejecuciones y recreaciones únicas, resultado de un proceso en el que los textos escritos representan solamente un punto de partida. Será preciso indagar acerca de las condiciones materiales de la puesta en voz y de las múltiples opciones autorales de énfasis o descarte que implica esta instancia, a fin de evaluar las tensiones que se generan entre la letra impresa y la palabra oral de la poeta. Desde el punto de vista

2 En realidad, toda forma de escritura es inseparable de la oralidad. Como explica Walter Ong, "leer un texto quiere decir convertirlo en sonidos, en voz alta o en la imaginación, sílaba por sílaba en la lectura lenta o a grandes rasgos en la rápida" (17). Este último tipo de lectura es habitual en una cultura altamente tecnológica como la nuestra.

$1] 1 \frac{\text { Revista Iberoamericana, Vol. LXXXV, Núm. 268, Julio-Septiembre 2019, } 997-1014}{\text { ISSN 0034-9631 (Impreso) }}$ 
de los lectores devenidos oyentes, intentaremos definir el territorio de la escucha que inauguran las versiones grabadas por Berenguer, un espacio semiótico sensorial que favorece la repercusión de los sonidos y los sentidos más allá de la lógica conceptual de las palabras.

\section{LA EXPERIMENTACIÓN CON EL SONIDO: DiCCIONES (1973)}

Los inicios literarios de Amanda Berenguer se sitúan en el contexto de la Generación del 45, llamada la "Generación crítica", de la que también formaron parte su esposo José Pedro Díaz, Ángel Rama, Ida Vitale, Carlos Maggi, Mario Benedetti e Idea Vilariño. Si sus tres primeros libros denotaban la influencia de Paul Valéry y la poesía pura, en $E l$ río (1952) Berenguer cultivó con éxito la poesía de corte filosófico o meditativo. ${ }^{3} \mathrm{De}$ allí en adelante cada poemario resultaría una aventura inédita en pos de nuevos temas, tonos y estrategias de la palabra. Al objetivismo volcado al paisaje y el imaginario vegetal de Suficiente maravilla (1953-1954), le siguió el decadentismo melancólico en La invitación (1957). La investigación acerca de la música de las coplas y vidalas de la poesía popular afloraba en Contracanto (1961), mientras que Declaración conjunta (1964) buceaba en la dinámica del erotismo. Ya Quehaceres e invenciones (1963) manifestaba el interés por los modelos de la ciencia y sus descubrimientos, tendencia que se profundizaría con las imágenes de las galaxias y de la cinta de Moebius en Materia prima (1966). En este libro clave Berenguer dio a conocer una voz propia, experimentada en el oficio, que apelaba al poema extenso como medio privilegiado de expresión (Puppo, "Zumba el ruido" 51-52).

Es por esos años que la autora desarrolló una auténtica teoría de la "poesía cinética", en consonancia con las búsquedas estéticas de otros grupos y artistas de neovanguardia. Luego de diez años de reflexión teórica y experimentación, en 1976 Berenguer dio a la imprenta Composición de lugar. En este libro exploró como nunca antes la dimensión visual de la escritura, hasta lograr el minimalismo del acróstico, el caligrama y la ecuación algebraica (Padín s/p, García Robles 20, Arbeleche 42). El volumen reúne diecinueve poemas designados como "ponientes sobre el mar"; a su vez cada uno de estos textos ofrece una segunda versión, más abstracta, y una tercera versión que apunta a la síntesis gráfica. El resultado es un conjunto peculiar de cincuenta y siete poemas que tematizan la puesta de sol sobre el Río de la Plata, mediante una estructura abierta y dinámica que amenaza la sintaxis lingüística y favorece distintas lecturas simultáneas. Lejos de pintar un idilio apacible, las imágenes de la naturaleza exponen la violencia,

3 Los tres poemarios de juventud -A través de los tiempos que llevan a la gran calma (1940), Canto hermético (1941) y Elegía por la muerte de Paul Valéry (1945)- no fueron incluidos por Berenguer en las dos ediciones de su obra conjunta, Poesías. 1949-1979 y Constelación del navio. Poesía 1950-2002. 
el dolor y el miedo que atravesaba un país donde el golpe de Estado del 27 de junio de 1973 había marcado el inicio de la dictadura (Puppo, "Teoría y práctica” 86-92).

Así como el juego con los grafemas halló su máxima expresión en Composición de lugar, la exploración de los sonidos fue protagonista en Dicciones. ${ }^{4}$ Este proyecto comenzó a gestarse en la casa de Amanda Berenguer, en Montevideo, el invierno de 1970. Según se explica en la parte trasera de la portada del álbum, la poeta registró su voz en una grabadora Philips EL3534, utilizando una cinta y un micrófono de la misma marca. Luego se realizó una regrabación en estudios Sondor en diciembre de 1970; allí también se llevó a cabo el corte y el procesado, en abril y mayo de 1973; finalmente, ese mismo año el disco fue prensado en Montevideo y lanzado al mercado por Ayuí / Tacuabé. ${ }^{5}$ El material se editó como disco de vinilo y como casete; en cada caso incluía un folleto con el texto íntegro de los poemas registrados en la grabación.
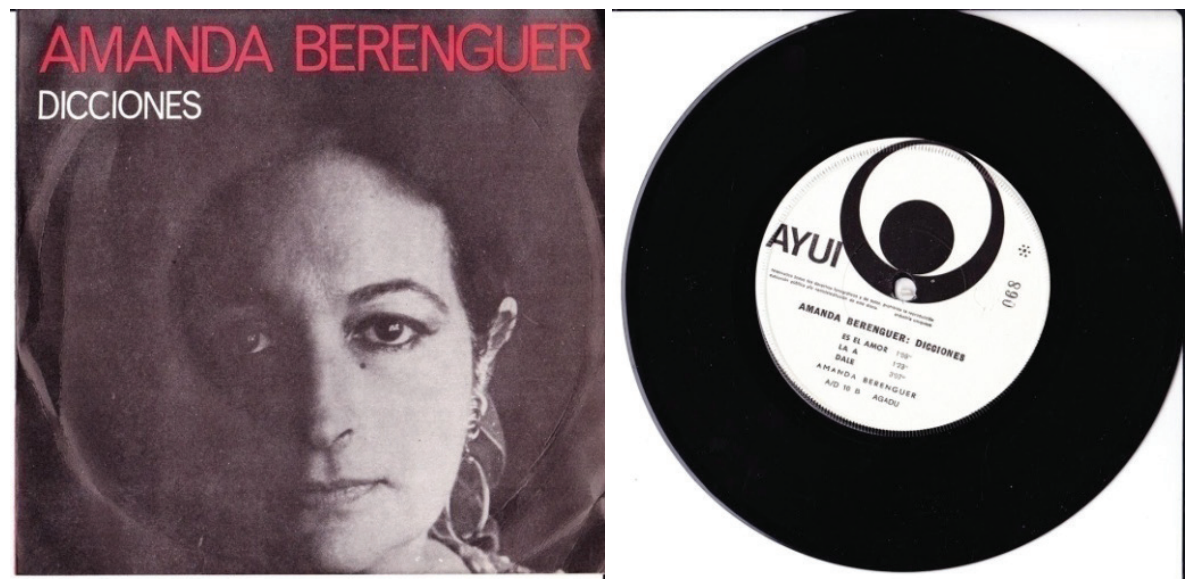

Imagen 1: Portada del disco simple Dicciones. Fotografía de Hermes Cuña. Carátula diseñada e impresa por Artegraf.

ImAgen 2: Cara B del disco de vinilo, donde se puede apreciar la numeración de cada ejemplar.

4 La etapa estrictamente experimental o neovanguardista de la poesía de Berenguer se prolongó hasta comienzos de los años ochenta. Permutaciones, repeticiones y diseños del espacio visual aparecen todavía en las series Conversación habilitante y derivados, Trazo y derivados (1976-1978), Arena (1978) y El tigre alfabetario (1979). Ahora bien, la lectura de entrevistas realizadas a la autora echa luz sobre la existencia de "Circuito reverberante", un texto que combinaba palabras, colores y sonidos, sobre el que la poeta afirmaba estar trabajando en 1990.

5 Entre 1972 y 1974 el sello Ayuí / Tacuabé editó discos con grabaciones de Juan Gelman y el Cuarteto Cedrón, Violeta Parra y Susana Rinaldi, entre otros.

$111 \frac{\text { Revista Iberoamericana, Vol. LXXXV, Núm. 268, Julio-Septiembre 2019, 997-1014 }}{\text { ISSN 0034-9631 (Impreso) }}$ 
La CARA A del simple presenta una introducción hablada de la autora que dura 2'03". A esta le siguen los poemas "Filoso como vidrio roto" (4') y "La guerra florida" (2'21"). La CARA B registra versiones de "Es el amor" (1'59”), "La a” (1'23”) y "Dale" (3'07"). Todos los poemas pertenecen a la serie El tigre alfabetario, publicada por primera vez en Poesías (1949-1979) (1980), con la excepción de "La a", que había aparecido en la primera edición de Contracanto (1957).

Como apuntó Barthes, el acto de escuchar la voz inaugura la relación con el otro, pues el sonido permite la delimitación de un espacio común (Barthes, "El acto de escuchar" 252). En la grabación de Berenguer, el íncipit oral establece un pacto de intimidad con los destinatarios: "Querido escucha: soy Amanda". ${ }^{6}$ En sus palabras preliminares la autora resalta el carácter imaginativo y experimental de su propuesta, que nace del ensayo de "formas de dicción diferentes". Sin apelar directamente a una motivación lúdica, subraya en cambio su interés por "arribar al contacto profundo con los demás".

A continuación la poeta explica que las versiones orales de sus poemas se rigen por una personalísima "Ley de gravedad", que invita a leer "de modo grave" determinadas vocales - $\underline{a}, \underline{o}-$ y palabras "que bajan y se hunden y se hacen pesadas". En contrapartida, resultan agudas la $\underline{\mathrm{i}}$ y la $\underline{\mathrm{u}}$, así como aquellos vocablos "que dan noción de altura, de vuelo, de elevación". Consciente de la limitación que ofrece cualquier intento de mimologismo, la autora reconoce haberse hallado "entre un problema fonético y otro significante".

Berenguer califica las Dicciones de "irrepetibles". Confiesa que no puede hacer dos versiones iguales y agrega: "Me dejaba llevar por una necesidad, una exigencia de la letra misma y entraba por una punta del poema y salía por la otra en un estado parecido a una entrega total y segura" (énfasis mío). De este modo se preconiza una fidelidad a la letra impresa que, como veremos, logra ir mano a mano con la libertad interpretativa. Por otro lado se destaca la "entrega" subjetiva de la poeta en el acto de ofrecer ante el micrófono su voz y, a través de ella, su persona entera.

Hacia el final de la introducción, Berenguer vuelve la atención nuevamente a los futuros receptores del fonograma. Se pone en su lugar y admite que "la primera audición desconcierta, quizá hasta moleste”. Agradecida de antemano, invita a los oyentes a hacer la experiencia de escuchar los poemas más de una vez.

6 Estas palabras iniciales provienen de nuestra transcripción del audio. En la parte posterior de la portada del disco se reproducen los argumentos principales de la introducción de Berenguer, pero con algunas modificaciones orientadas a la recepción visual del texto (Ver imagen 3).

1]1 1 Revista Iberoamericana, Vol. LXXXV, Núm. 268, Julio-Septiembre 2019, 997-1014 


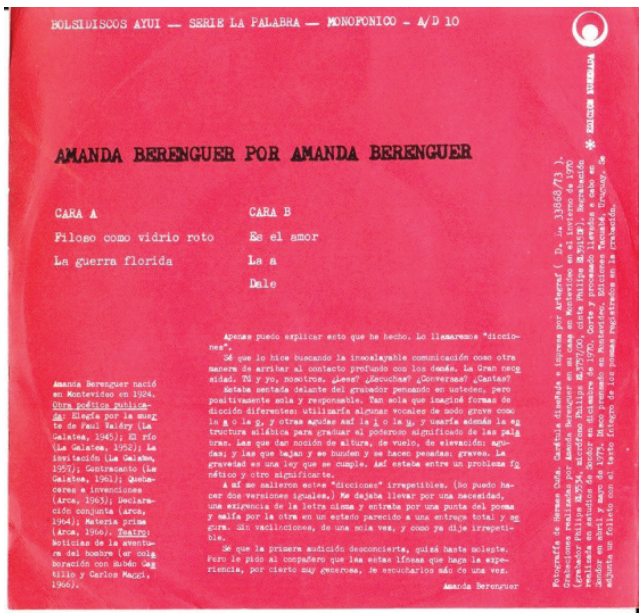

Imagen 3: Parte trasera de la portada de Dicciones (1973).

El impacto que producen las grabaciones depende mucho del gusto y los hábitos de escucha de cada oyente. Para no caer en una serie de impresiones personales, intentaremos describir algunos rasgos salientes de ellas. En primer lugar, diremos que las puestas en voz de Dicciones reproducen los textos en un tempo más lento que el de la lectura habitual. Las sílabas se alargan por el estiramiento de los sonidos vocálicos, que se combina con el énfasis puesto en algunas consonantes (la $\mathbf{n}$, la rr, la s). En todo momento, la lectura en voz alta intenta traducir al plano del sonido la disposición gráfica de las palabras: los versos forman unidades fónico-rítmicas que se agrupan en estrofas más o menos delineadas; la puntuación y los espacios en blanco al interior de los versos señalan pausas; en los versos finales de cada poema se ralentiza el ritmo.

Tomemos en consideración la puesta en voz de la primera parte del poema "Filoso como vidrio roto": 7

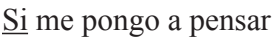
se desnuda la manzana.

Carnada se hace por arte

4 de encantamiento

y al peinarme anguilas saltan

7 La versión escrita del poema, que tomamos como base de comparación, es la que se ofrece en Constelación del Navio. Poesía 1950-2002 (388). 
llegan pulpos estrellados

en la red.

$\sim$ Retorcidas ideas enrulan la cabeza: $\sim$ todo es espuma crepitante en los espejos. dejo a la leche irse por

el fuego en el centro mismo del invento ... $\quad \ldots \quad \ldots$

La audición de este fragmento permite constatar que en determinadas ocasiones, pero no siempre, se cumple la "Ley de gravedad" anunciada por la autora. Se pronuncian con un tono agudo las sílabas que contienen "i" y "u" en "Sii" (verso 1), "desnuda" (2), "anguilas" (5), "pulpos" (6) y "espuma" (9), así como las sílabas iniciales de "saltan" (5) y "estrellados (6), palabras que por su significado se asocian a la altura. Pero también se pronuncian agudas las sílabas acentuadas de "carnada" (3) y "mismo" (13), a pesar de que no responden a ninguno de los criterios anteriores. Por otra parte, el mimetismo sonoro genera una lectura ondulante $[\tilde{}]$ ] del verso 8 , que introduce la imagen de los rulos. En los versos 11-13 el canto [\}] se apodera de la voz de la poeta. Este procedimiento será frecuente en varias series de versos de este y de los otros poemas del disco. ${ }^{8}$

Desde el punto de vista del mimologismo fónico, se destaca también la puesta en voz de "Dale", poema donde la lectura acentúa el ritmo quebrado de la percusión en los versos "ba/ti/te / ten/so tam/bor" y "mar/ca/te el pa/so". Asimismo la versión en audio de este poema culmina con una especie de grand finale, mediante la doble repetición de la palabra "dale". Además de este caso, se registran otras repeticiones y un cambio de verbo en las versiones orales. ${ }^{9}$ Estas transformaciones o desvíos remiten a una tensión entre la letra y su doble, el sonido articulado. Como lo demostró Ana Porrúa al analizar un variado corpus dentro de la poesía argentina, tales procesos de simetría y asimetría determinan la actualización de los textos poéticos en nuevos contextos y a la luz de diferentes tradiciones, en tanto que ponen en evidencia las fricciones de aquello que Peter Szondy llamó "la escucha bífida", o sea, la escucha de quien produce el sonido (Porrúa, Caligrafia tonal 147-206).

Las puestas en voz de Dicciones refuerzan la oralidad que ya estaba implícita en la letra escrita. La voz física de Amanda Berenguer confirma la singularidad de la voz

8 Las versiones en audio de "Es el amor" y "Dale" tienen la mayoría de versos cantados.

9 La puesta en voz de "Filoso como vidrio roto" agrega una cuarta vez el sintagma "estoy viva" (Constelación 388), en tanto que la de "Guerra florida" triplica "palpitante" y duplica "victorioso" (406). Asimismo, la frase "se convierte en noria" (de "Filoso...") deviene "se retuerce en noria" en la versión oral (388). 
poética que enuncia sus textos, en lo que hace a sus rasgos individuales y a las marcas de su inscripción social. Como sello propio se destacan la preferencia por el riesgo, la modulación sutil, los cambios de tono, la unidad buscada entre el sonido y el significado. La identidad rioplatense se afirma en la pronunciación de la " $y$ " fricativa y la "s intervocálica aspirada. Por lo demás el canto redobla la apuesta, ya que nos enfrenta a los oyentes con aquello que Barthes llamó el "grano" de la voz, una voluptuosidad distintiva que inmediatamente nos obliga a establecer con ella una relación de amor $\mathrm{u}$ odio ("El «grano» de la voz" 268). Las versiones de "Es el amor" y "Dale" incluyen bellas melodías en las cuales el timbre de voz de Amanda Berenguer recuerda al de la escritora y música María Elena Walsh. El tempo lento y algunas combinaciones de dos o tres notas remiten a la técnica de composición de las bagualas y otras formas de la música popular latinoamericana.

Luis Bravo iguala con "una especie de trance" ese estado de "entrega total" al que hacía referencia la propia poeta en la introducción a Dicciones. El crítico uruguayo destaca el carácter no convencional de la lectura de Berenguer, cuyo resultado "se cuenta entre lo más original del período" (Bravo, Voz y palabra 203). Efectivamente los poemas en audio pertenecen a la fase más experimental de la producción de la autora y merecen ser considerados junto a otras manifestaciones de neovanguardia.

Desde la escena inicial que sitúa a una mujer sola frente a una grabadora en su casa de Montevideo, es posible desandar un camino de búsqueda artística que se retrotrae a los poemas fonéticos de Hugo Ball, Raoul Hausmann y Kurt Schwitters en el seno del dadaísmo, las transmisiones radiales de Jean Cocteau o la poesía sonora diseñada para el magnetófono por Bernard Heidsieck y Henri Chopin a mediados de los cincuenta. El disco de Berenguer se inserta también en una tradición de poesía sonora compuesta y registrada en Uruguay, que hunde sus raíces en la poesía oral de los afrodescendientes, los "recitadores" populares y los "declamadores" de la poesía culta, y que alcanzó un gran auge en los sesenta con las grabaciones de poetas y cantautores como El Pampa González, Alcides Astiazarán, Juan Capagorry, Daniel Viglietti, Mario Benedetti, Alberto Candeau y Alfredo Zitarrosa. A eso hay que agregar las particulares puestas en escena que hizo de sus poemas el escritor y músico Luis Campodónico en el Sodre (Servicio Oficial de Difusión Radio Eléctrica), entre 1951 y 1961, y la visibilidad alcanzada por la poesía sonora en "La Expo/Internacional de Novísima Poesía - 69", que arribó a Montevideo meses después de que Edgardo Antonio Vigo la estrenara en el Instituto Di Tella de Buenos Aires (Italiano 11-17).

\section{El terRitorio DE LA ESCUCHA ACTIVA: LA ESTRANGUlADORA (1998)}

Después del experimentalismo que caracterizó las producciones de Amanda Berenguer de los setenta, la experimentación poética en sentido amplio continuó presente en sus obras posteriores, que incluyen: Identidad de ciertas frutas (1983),

$1] 1$ Revista Iberoamericana, Vol. LXXXV, Núm. 268, Julio-Septiembre 2019, 997-1014 
un volumen que se inscribe en la tradición objetivista de William Carlos Williams; La dama de Elche (1987), el libro más premiado de la autora, que propone un viaje al pasado a través de la palabra y sus resonancias en distintas geografías; Los signos sobre la mesa (1988), una lúcida reflexión sobre la historia de la tortura y, en particular, sobre su uso en la dictadura militar uruguaya; La botella verde (1995), un poemario que gira en torno a un objeto topológico, la botella de Klein.

Según constatan las cronologías biográficas, a lo largo de esos años Berenguer realizó otras actividades en paralelo con el trabajo de escritura. Entre 1979 y 1980 acompañó a su esposo José Pedro Díaz a su exilio académico en Estados Unidos, y allí realizó presentaciones audiovisuales de su poesía en distintas universidades e instituciones. ${ }^{10}$ Ya de regreso en Montevideo, en 1982 organizó el espectáculo Lectura concertante, que incluía lecturas de poesía y prosa y música, junto a Marosa Di Giorgio, Miguel Ángel Campodónico y el músico Juan José Iturriberry (Constelación 669-672). No es un dato menor que Berenguer compartiera escenario con Campodónico, un escritor habituado a la escena teatral y el medio radiofónico, y con la siempre imponderable Marosa, cuyas performances se cuentan entre las más notables que ha generado la poesía de nuestro continente. ${ }^{11}$

La experiencia de Dicciones y de sus múltiples lecturas frente a una audiencia impulsó seguramente a Berenguer a registrar la puesta en voz de un largo poema compuesto en la década del noventa, La estranguladora. En 1998 este se editó como libro en Montevideo, bajo el sello Cal y Canto, acompañado de un casete (Imagen 4). Ese mismo año obtuvo el Primer Premio de poesía del Ministerio de Educación y Cultura del Uruguay.

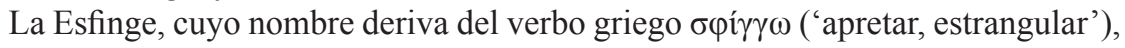
es la imagen central del poemario, que se desdobla en otras criaturas míticas como la gigantesca Ave Roc que atacó a Simbad el Marino o la serpiente emplumada de las cosmovisiones mesoamericanas. En un clima de fantasía, recuerdo y pesadilla, la hablante poética narra su encuentro con "el monstruo" que ella misma ha parido (Constelación 653). Al principio la Esfinge suena bromista y banal, pero poco a poco su presencia irá enfrentando a la hablante con el drama del tiempo y la finitud.

${ }^{10}$ Ignacio Bajter comenta acerca de este período del que, lamentablemente, no hay registro: "Mientras duró, el tour universitario dio lugar a una secuencia de experiencias performáticas dominadas por la puesta del texto/imagen en slide y el trabajo de su voz con la resonancia de otras" (Bajter 206).

${ }^{11}$ Como bien señala Irina Garbatzky, en las vocalizaciones grabadas y los recitales que ofrecía Marosa Di Giorgio aún eran perceptibles las huellas lejanas de la declamación de poesía, un "arte" promovido en América por las políticas de escolarización de fines del siglo XIX y principios del XX. Pero alejándose del decoro y la mesura que garantizaba una técnica basada en la lógica de las correspondencias, las puestas en voz de Marosa emulaban, más bien, el histrionismo declamatorio de Berta Singerman. En los poemas en audio reunidos en Diadema (1994), la voz de la poeta se desliza teatralmente hacia el canto, el susurro, la voz ronca, la impostación y la voz dislocada que roza lo siniestro (Garbatzky 43-50). 

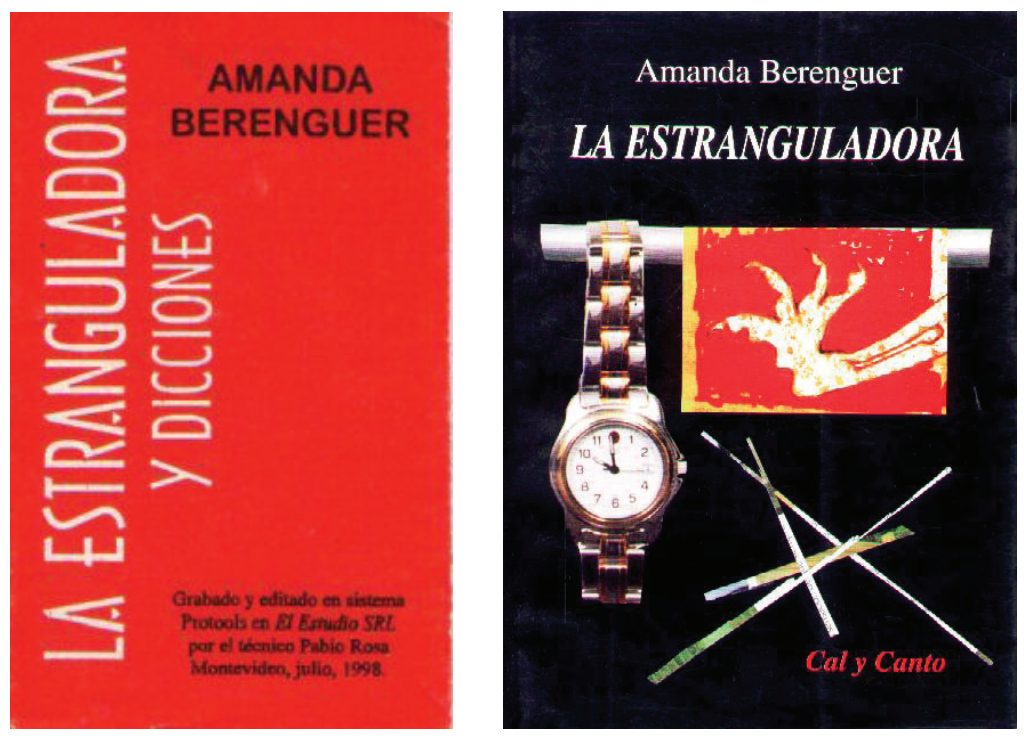

IMAGEN 4: Portada del casete que acompañaba la primera edición de La estranguladora (1998). Imagen 5: Portada del libro. Collage de la autora.

Compuesto por jirones de frases, discursos y anécdotas biográficas, La estranguladora resulta un poema complejo, de difícil lectura. El teatro de la muerte se compone mediante citas de otros (los poetas nahuas, Píndaro, San Juan de la Cruz, Paul Valéry) y alusiones a Edipo, el Conde de Lautréamont, Frida Kahlo y la cantante Madonna. En el collage que la propia autora diseñó para la portada se destacan tres elementos alegóricos: un reloj pulsera femenino, una garra en tensión y una letra "A" formada con tiritas de papel (Imagen 5). La reunión de objetos recuerda el azar del catálogo o, acaso, el inventario que podríamos hallar en un testamento. La inicial del nombre instala la firma perpetuando la ausencia física de la persona, como si todo rastro de vida ya hubiera sido succionado por el inquietante fondo negro de la composición (Puppo, "Contra el fondo" s/p).

El poema en audio dura 27'33'. Así como el collage de la portada resulta un umbral escenográfico para la letra escrita, un silencio previo de veintiséis segundos es el único protocolo que anticipa la escucha. En realidad se trata de un silencio de palabras, en el cual parecen superponerse siseos, murmullos y vocalizaciones asordinadas. De pronto irrumpe una voz femenina que lee el título del poema: es una voz potente y melodiosa que en el imaginario de los oyentes difícilmente se asociaría a la figura de una autora

$1] 1$ Revista Iberoamericana, Vol. LXXXV, Núm. 268, Julio-Septiembre 2019, 997-1014 
septuagenaria. Es una voz segura, que trasunta la agilidad de la vista y de la lengua; autoconsciente, porque busca una entonación distintiva sin caer en la solemnidad. Por otra parte se muestra como una voz cercana, que se aproxima al micrófono sin necesidad de elevar el volumen. Y a medida que avanza la narración en primera persona, la voz no teme volverse íntima, como cuando revela su apodo infantil -"Minye"-y los nombres de sus seres queridos: "la abuela Pepa", su madre, su marido José Pedro, su hijo Álvaro, su nuera Sylvia.

La puesta en voz mantiene el equilibrio que propone el texto escrito entre un habla coloquial contemporánea, que reproduce chistes, juegos verbales y referencias a la cultura de masas, y una dicción poética omnipresente que organiza el material lingüístico en estructuras cuidadosamente sopesadas y pulidas. En general la lectura de Berenguer enfatiza las vocales abiertas y las sílabas acentuadas, prioriza las consonantes nasales y acelera o retarda el ritmo para acompañar el suspenso del relato. Examinemos con más detalle una estrofa que pertenece a los primeros segmentos del poema:

Karamazovi / los bigotes espesos de una morsa

o de Nietzche / y unas palabras en el espejo:

04 "habré vivido parecido a los dioses / y eso basta" /

¿va a durar mucho más? dijeron /

06 perdí la cara de Hölderlin / y me miró sedoso

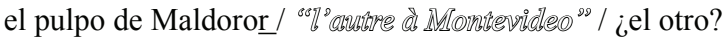

08 y Delmira de rojo / y mamá / y mamá

con sombrero pequeño con larga pluma de faisán

10 ¿tía Ana / muerta de tisis? / tres rosas amarillas /

Carver con las copas servidas / ¿quién está soñando?

12 pregunta Emily hamacándose / y Marosa con gladiolo - icree Vd. en los presentimientos? /

14 Alvaro y Sylvia asienten y José Pedro / sentados en el borde de la cama /

16 más dos aspirinas y redoxón / más el jazmín de noviembre / y un vaso de agua / mejor /

18 mejor / -me siento mejor/

¿me pueden decir dónde estaba ese pájaro? (Constelación 652-53)

En este fragmento la hablante poética describe la atmósfera alucinatoria de un estado febril, en donde las visiones se confunden con las figuras y voces de los familiares sentados al borde de la cama. Una misma isotopía de la muerte y la enfermedad reúne personajes e índices ficcionales con versos y pasajes de autores admirados: Bram Stoker, Dostoievski, Nietzsche, Hölderlin, Leautréamont, Delmira Agustini,

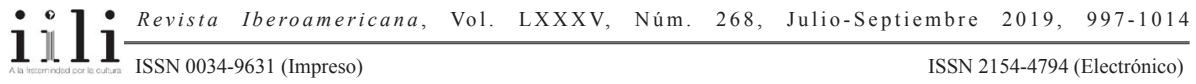


Raymond Carver, Emily Dickinson, Marosa Di Giorgio. ${ }^{12}$ La puesta en voz subraya la continuidad entre lo real y lo imaginario mediante un ritmo constante, arrasador, que abraza encabalgamientos y cambios de tono bruscos. El ritmo aparece entonces como el "pulso" del poema, "un sistema nervioso armado" sobre el cual cada tono imprime "una química, una densidad que permea las palabras", según la distinción de Alicia Genovese (41).

La pronunciación se impone por encima de la articulación, como quería Barthes, cuando la autora subraya las aliteraciones de $\underline{\mathbf{r}}$ (versos 7, 8, 10 y 11) o cuando lee el sintagma en francés (7). Asimismo la dramatización cobra un rol importante en la versión grabada de este extenso poema narrativo. En la estrofa citada, las dotes actorales de Berenguer se advierten en la interpretación de dos fragmentos de diálogo: una pregunta leída imitando la entonación de Marosa (13), y una respuesta en tres partes con la que la hablante intenta aliviar la preocupación de su familia (17-18).

A diferencia de los ensayos experimentales de Dicciones, la versión en audio de La estranguladora no se aleja del paradigma convencional de las lecturas de poesía. Con mínimas variaciones a la letra, la puesta en voz de Amanda Berenguer confirma la prerrogativa literal del poema, al tiempo que subraya la oralidad implícita de la letra escrita. ${ }^{13}$ Jill Kuhnheim y Jacob Rapp consideran que la lectura de la autora uruguaya refuerza las conexiones "cerebrales" del poema, que responde a un "tono analítico" (Kuhnheim y Rapp 312-313). Es claro que no nos hallamos ahora ante la fuga libertaria de los significantes sonoros, sino frente a un más allá que potencia el mensaje verbal: un exceso (de intensidad, de gesto, de ruido) no asimilable a la prosodia y la sintaxis en la medida en que constituye, siguiendo a Benveniste, la "semántica de lo suprasegmental" (Pollicino 39). El ritmo aparece entonces como un significado en sí mismo que traduce "la organización del sujeto como discurso" (Meschonnic 70).

La voz puede ser comprendida desde una perspectiva prelingüística, que la asocia al espacio materno de la Chora semiótica descrita por Kristeva, o bien desde un punto de vista poslingüístico, que advierte en ella una superación del lenguaje mediante la apertura de un espacio otro, como sucede en la risa o el canto (Milone 44). Mladen Dolar observa que la voz está dotada de profundidad y remite a un significado originario; de ahí su capacidad para remitir a lo divino y lo sobrenatural (Dolar 31). En algunos momentos del audio de La estranguladora, la voz de Amanda Berenguer deviene receptáculo de las palabras de la Esfinge. Y como sugirió Luis Bravo, al toparnos con

12 En el fragmento seleccionado también hay una alusión al escritor Anton Chejov, cuyos últimos días son recreados por Carver en el cuento "Errand". El poema menciona el título con el que se conoce este relato en castellano: "Tres rosas amarillas".

13 La única variación del audio con respecto a la versión impresa, en el fragmento citado, es la supresión del adverbio "más" en el verso 5.

$1] 1$ Revista Iberoamericana, Vol. LXXXV, Núm. 268, Julio-Septiembre 2019, 997-1014 
esa voz los oyentes experimentamos la extraña sensación de haber viajado a Delfos (Bravo, "Amanda Berenguer").

El territorio de la escucha que genera el poema de 1998 es un espacio polisémico, donde conviven múltiples tonos y niveles de significación, capaces de enlazar lo sagrado y lo prosaico, la violencia y el terror, la meditación sobre la muerte y la pregunta por el sentido de la poesía. Una vez traspasadas las fronteras de lo conceptual, los/as oyentes nos entregamos a la forma aurática que el poema despierta en nosotros/as (Roubaud 19). Percibimos la suspensión del aliento y la textura de una voz que expresa la incertidumbre ante el misterio, el miedo experimentado de niña, la ternura al pronunciar los nombres amados. La palabra articulada de Amanda Berenguer nos habla de su tiempo y su lugar en el mundo, pero también de la memoria de los pueblos olvidados y de la angustia existencial de los seres humanos de todos los tiempos, de un presente cultural y social, de una genealogía femenina que está viva y habla a través de su voz.

\section{Poesía y Resonancia. A modo de CONCLUSión}

A partir de la fenomenología de Husserl, Derrida concluye que oírse hablar es introducir el ojo y el mundo en el habla (Derrida 145). Por nuestra parte comprobamos como, al leer en voz alta su texto, la poeta rompe el círculo de soledad y proyecta su palabra en el aire para que pueda llegar físicamente a los otros. Y gracias a la mediación del soporte tecnológico, su grabación podrá ser escuchada por diferentes audiencias en nuevas y múltiples coordenadas de tiempo y espacio. Una primera constatación es que la puesta en voz subraya la multimedialidad de la poesía como género, es decir, su proclividad a la diseminación a través de diferentes canales de comunicación (Reed 272). En el caso de Amanda Berenguer, el deseo de conectar más fuertemente con los receptores va de la mano de una voluntad constante de intensificar y renovar los recursos que potencian la "apertura" del poema hacia distintos estilos, formatos y soportes (Berenguer, El monstruo incesante 91).

En segundo lugar, hemos observado cómo las performances orales constituyen nuevas versiones de los poemas escritos, al volver físicamente perceptible la entidad "cuasitrascendental" de la letra (Reed 272). Tras haber confrontado las dos grabaciones de Amanda Berenguer, podemos concluir que, en cada caso, el pasaje de la letra impresa a la vocalización ofreció una oportunidad única para que la autora pudiera seleccionar, acentuar o minimizar algunos signos y algunas significaciones de sus textos. Pero más allá de brindar posibles indicios en favor de una interpretación determinada, la puesta en voz logra expresar, por una parte, lo no dicho del lenguaje, aquello que Barthes describe como "lo implícito, lo indirecto, lo suplementario, lo aplazado" (255), y por otra, lo que excede al lenguaje, es decir, el universo preverbal de emociones y afectos de un cuerpo vivo. 
Una tercera conclusión se deriva del carácter tensional y problemático del vínculo que une la letra y la voz. Recordemos que, paradójicamente, al realizar las vocalizaciones más creativas y experimentales (en Dicciones), Berenguer aseguraba estar siguiendo "una exigencia de la letra misma". Y a esta asimetría se suma el hecho de que no existe tampoco una escucha limpia por parte del receptor, cuya respuesta siempre está condicionada por determinaciones culturales e históricas (Porrúa, "La escucha" 144).

Finalmente quisiéramos concluir estas reflexiones acerca de las puestas en voz de los poemas de Amanda Berenguer haciendo referencia al concepto de repercusión o resonancia, que varios autores asocian estrechamente a la poesía (Blanchot 414, Collot 15). ${ }^{14}$ Gaston Bachelard señaló que la imagen poética no es un simple eco del pasado, sino la repercusión (retentissement) de los ecos de un pasado que aún no se extinguen (Bachelard 7-11). Esta idea es deudora del pensamiento del psiquiatra Eugène Minkowski, quien definió la repercusión como "un fenómeno esencial de la vida" que no se reduce a la esfera auditiva (Diez 187). Más tarde Paul Ricœur observó cómo la memoria y la lectura poética dependen de un "fenómeno de repercusión, de eco o de reverberación", puesto que en ambas instancias "la imaginación se difunde en todas las direcciones, reanimando experiencias anteriores, despertando recuerdos dormidos, irrigando campos sensoriales adyacentes" (Ricœur 220). La resonancia de la poesía tiene que ver con el poder de evocación de las imágenes, las palabras y los sonidos, y al menos los dos últimos solo existen en dependencia de una voz capaz de materializar un espacio único y singular, moldeado por la intimidad de un sujeto y abierto a la escucha de los otros.

\section{BiBLIOGRAFÍA CITADA}

Agamben, Giorgio. "Vocation and Voice". Qui Parle 10/2 (1997): 89-100.

Arbeleche, Jorge. "La poesía de Amanda Berenguer". Responsabilidad de la poesía. Montevideo: Ediciones Rosgal, 1997. 40-45.

Bachelard, Gaston. La poética del espacio. Buenos Aires: Fondo de Cultura Económica, 2000.

Bajter, Ignacio. "La casa móvil: Amanda Berenguer ante la traducción". Revista de la Biblioteca Nacional, Época 3, 4. 6-7 (2012). 199-221. Web. 21 Nov. 2014. <http:// www.bibliotecadelbicentenario.gub.uy/innovaportal/file/53038/1/revista biblioteca_nacional_6_7_2012.pdf >.

Barthes, Roland. "El acto de escuchar". Lo obvio y lo obtuso. Imágenes, gestos, voces. Barcelona: Paidós, 1986. 243-256.

\footnotetext{
14 Para un análisis de este término, sus antecedentes y el uso que le da Paul Ricœur en su teoría de la imaginación, remitimos al trabajo de Diez (2014).
}

$1] 1$ Revista Iberoamericana, Vol. LXXXV, Núm. 268, Julio-Septiembre 2019, 997-1014 
“El «grano» de la voz”. Lo obvio y lo obtuso. Imágenes, gestos, voces. Barcelona:

Paidós, 1986. 262-271.

Berenguer, Amanda. La botella verde. Montevideo: Cal y Canto, 1995.

Constelación del Navío. Poesía 1950-2002. Montevideo: H Editores, 2002.

Dicciones. Fonograma. Montevideo: Ayuí / Tacuabé, 1973.

La estranguladora y Dicciones. Libro y casete. Montevideo: Editorial Cal y Canto, 1998.

El monstruo incesante: (expedición de caza). Montevideo: Arca, 1990.

Poesías 1949-1979. Buenos Aires: Calicanto, 1980.

Los signos sobre la mesa. Montevideo: Universidad de la República, 1987.

Blanchot, Maurice. El diálogo inconcluso. Caracas: Monte Ávila, 1970.

Bravo, Luis. Voz y palabra. Historia transversal de la poesía uruguaya, 1950-1973.

Montevideo: Estuario Editora, 2012.

“Amanda Berenguer: creatura especular". Jornal de Poesia-Banda Hispânica

(2001): s/p. <http://www.jornaldepoesia.jor.br/bh2berenguer1.html>. 27 feb. 2015.

"La puesta en voz de la poesía, antiguo arte multimedia". [sic] 1.1 (2011):

6-21. <http://www.aplu.org.uy/wp-content/uploads/2010/04/SIC_abril_20111. pdf>. 28 junio 2013.

Brik, Osip. "Ritmo y sintaxis". Teoría de la literatura de los formalistas rusos.

Tzvetan Todorov, ed. Ana María Nethol, trad. Buenos Aires: Siglo Veintiuno Editores, 2004. 107-114.

Collot, Michel. Paysage et poésie du romantisme à nos jours. París : José Corti, 2005. Derrida, Jacques. La voz y el fenómeno. Introducción al problema del signo en la fenomenología de Husserl. Francisco Peñalver, trad. Valencia: Pretextos, 1985.

Diez, Francisco. "A la escucha de la libertad en el pensamiento de Paul Ricœur". La libertad del Espíritu. Tres figuras en diálogo interdisciplinario. Cecilia Avenatti de Palumbo, coord. Buenos Aires: Ágape / Universidad Católica Argentina, 2014. 179-196.

Dolar, Mladen. A Voice and Nothing More. Cambridge, MA: MIT Press, 2006.

Domínguez Caparrós, José. Métrica y Poética. Bases para la fundamentación de la métrica en la teoría literaria moderna. Madrid: UNED, 2010.

Dorra, Raúl. La casa y el caracol (para una semiótica del cuerpo). $2^{\text {a }}$ edición. Córdoba: Alción, 2006.

Garbatzky, Irina. “Marosa di Giorgio: la voz en fuga”. Hispamérica XLI (2012). 43-50. García Robles, Hugo. "Constancia de la razón poética”. Cuadernos Hispanoamericanos 632 (2003). Dossier: Aspectos de la cultura uruguaya. 19-28.

Genette, Gérard. Mimologiques. Voyage en Cratylie. París: Seuil, 1976.

Genovese, Alicia. Leer poesía. Lo leve, lo grave, lo opaco. Buenos Aires: FCE, 2011. 
Italiano, Juan Ángel. El placer granulado de la voz. La poesía sonora y sus aledaños en el Uruguay (Una breve aproximación, 1830-2000). Montevideo: Ediciones del Cementerio, 2014. <http://archive.org/stream/ ElPlacerGranuladoDeLaVozJuanAngelItaliano/El\%20placer\%20granulado $\% 20$ de\%201a\%20voz\%20-\%20Juan\%20Angel\%20Italiano\#page/n31/mode/2up>. 26 feb. 2015.

Jakobson, Roman. “Lingüística y poética”. Ensayos de lingüística general. Jem Cabanes, trad. Barcelona: Seix Barral, 1981. 347-395.

Kuhnheim, Jill S. y Rapp, Jacob. "Una puesta en voz neobarroca: Diadema de Marosa di Giorgio". Revista de Crítica Literaria Latinoamericana XXXVIII/76 (2012): 297-316.

Masiello, Francine. El cuerpo de la voz (poesía, ética y cultura). Rosario: Beatriz Viterbo, 2013.

Meschonnic, Henri. Critique du rythme. Anthropologie historique du langage. Lagrasse: Verdier, 1982.

Milone, Cecilia. "Lenguaje y voz. Pensamiento contemporáneo y experiencia poética". Outra travessia 15 (2013): 37-55.

Monteleone, Jorge. "Voz en sombras: poesía y oralidad". Boletín 7 (1999): 147-153.

Ong, Walter. Oralidad y escritura. Tecnologías de la palabra. Angélica Scher, trad. Buenos Aires: FCE, 1993.

Padín, Clemente. "V+V. Lo Verbal y lo Visual en el arte uruguayo. Segunda Parte". Escáner Cultural. El Mundo del Arte 20 (2000): s/p. <http://www.escaner.cl/ escaner20/acorreo.html>. 12 oct. 2011.

Pollicino, Simona. "La notion de rythme entre poésie et musique". Synergies Espagne 4 (2011): 35-42.

Porrúa, Ana. Caligrafía tonal. Ensayos sobre poesía. Buenos Aires: Entropía, 2011. "La escucha y sus párpados". Badebec 4/7 (2014). Dossier: Performances poéticas / Poéticas de la performance. Garbatzky, Irina, directora. 143-158.

Puppo, María Lucía. “Teoría y práctica de la poesía cinética en Composición de lugar (1976) de Amanda Berenguer”. Letras 69-70 (2014). Monográfico: Teoría y análisis del discurso lírico. 79-99.

"Contra el fondo negro: autofiguración y poética en dos collages de Amanda Berenguer". Actas de las I Jornadas Interdisciplinarias sobre Estudios de Género y Estudios Visuales "La producción visual de la sexualidad”. Universidad Nacional de Mar del Plata: 2014. CD-Rom.

“'Zumba el ruido de fondo de la galaxia': poesía y astronomía en Amanda Berenguer". Memoria e imaginación poética en el Cono Sur, 1960-2010. Salomone, Alicia, editora. Buenos Aires: Corregidor, 2015. 51-70.

$1] 1 \frac{\text { Revista Iberoamericana, Vol. LXXXV, Núm. 268, Julio-Septiembre 2019, } 997-1014}{\text { ISSN 0034-9631 (Impreso) }}$ 
Reed, Brian M. "Visual Experiment and Oral Performance." The Sound of Poetry, The Poetry of Sound. Marjorie Perloff y Craig Dworkin, eds. Chicago: The U of Chicago P, 2009. 270-284

Ricœur, Paul. Du texte à l'action. Essais d'herméneutique II. París: Seuil, 1986.

Roubaud, Jacques. "Prelude: Poetry and Orality." The Sound of Poetry, The Poetry of Sound. Marjorie Perloff y Craig Dworkin, eds. Jean-Jacques Poucel, trad. Chicago: The U of Chicago P, 2009. 18-25.

Stevens, Wallace. El elemento irracional en la poesía. Patricia Gola, trad. Córdoba: Alción, 2010.

Tiniánov, Iuri. El problema de la lengua poética. Eugenio López Arriazu, trad. Buenos Aires: Dedalus, 2010.

Vega Ramos, María José. El secreto artificio: maronolatría y tradición pontaniana en la poética del Renacimiento. Madrid: CSIC/Universidad de Extremadura, 1992.

Palabras clave: Puesta en voz, multimedialidad, resonancia/repercusión, excedente del lenguage

Recibido: $\quad 23$ marzo 2016

Aceptado: $\quad 21$ abril 2016 